\title{
High Burn-Up Plutonium Isotopic Compositions Recommended for Use in Shielding Analysis
}

by

M. G. Zimmerman

June 1977

Prepared for the Energy Research and Development Administration under Contract EY-76-C-06-1830 

BNWL -2282

UC -78

33679000628711

HIGH BURN-UP PLUTONILM ISOTOPIC COMPOSITIONS

RECOMMENDED FOR USE IN SHIELDING ANALYSIS

by

M. G. Zimmermân

June 1977

BATTELLE

Pacific Northwest Laboratories

Richland, Washington 99352 
,

.

.

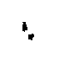




\section{ACKNOWLEDGMENT}

This report summarizes a study conducted by Battelle, Pacific Northwest Laboratories for the U.S. Energy Research and Development Agency under Contract No. E(45-1)-1830. The author wishes to thank E. T. Merri11 and $C$. M. Heeb for their technical contributions to the data used, C. L. Brown for his assistance in preparing the report, and John Church, E.I. duPont de Nemours \& Co., SRL, for his review and helpful suggestions regarding applicability to the industry. 
.

. 
Isotopic compositions for plutonium generated and recycled in LWR's have been estimated for use in shielding calculations. The values were obtained by averaging isotopic values from many sources in the literature. These isotopic values should provide the basis for a reasonable prediction of exposure rates from the range of LWR fuel expected in the future. The isotopic compositions given are meant to be used for shielding calculations, and the values are not necessarily applicable to other forms of analysis, such as inventory assessment or criticality safety. Final results are presented in Table 1.

TABLE 1. High Burn-Up Plutonium Isotopic Compositions

Recormended for Use In Shielding Analys is

Composition, wt\%, At End of Cycle

\begin{tabular}{ccccccc} 
Isotope & $\begin{array}{c}\text { Equilibrium } \\
\text { Uranium } \\
\text { Cycle }\end{array}$ & & $\begin{array}{c}\text { First Fu } \\
\text { Recycle }\end{array}$ & $\begin{array}{c}\text { Second Pu } \\
\text { Recycle }\end{array}$ & $\begin{array}{c}\text { Third Pu } \\
\text { Recycle }\end{array}$ & $\begin{array}{c}\text { Fourth Pu } \\
\text { Recycle }\end{array}$ \\
\cline { 1 - 1 } Pu-236 & $0.08 \mathrm{ppm}$ & & $0.06 \mathrm{ppm}$ & $0.06 \mathrm{ppm}$ & $0.06 \mathrm{ppm}$ & $0.06 \mathrm{ppm}$ \\
Pu-238 & 2. & 2.5 & 3.5 & 4. & 5. \\
Pu-239 & 57. & 43. & 37.2 & 29. & 26. \\
Pu-240 & 24. & 28.5 & 30.2 & & 29. & 26. \\
Pu-241 & 12. & 16. & 16.1 & 19. & 19. \\
Pu-242 & 5. & 10. & 13. & 19. & 24.
\end{tabular}

These compositions provide a resource for shielding and dose rate analys is of new facilities that will fabricate and process high-burnup plutonium fuel. 
TABLE OF CONTENTS

ACKNOWLEDGMENT. ............... ii SUMMARY . . . . . . . . . . . . . $i i i$

LIST OF TABLES. . . . . . . . . $v$ LIST OF FIGURES ................ v INTRODUCTION. .................. 1 DISCUSSION. . . . . . . . . . . . . . . 1

PLUTONIUM ISOTOPE PRODUCTION ....... 2

RADIATION AND SHIELDING CHARACTERISTICS OF

PLUTONIUM ISOTOPES ............ 3

REPORTED PLUTONIUM ISOTOPIC COMPOSITIONS

FOR $\mathrm{UO}_{2}$ AND PU-UO $\mathrm{O}_{2}$ FUELS ......... 8 REFERENCES. ............ 16 


\section{$\underline{\text { LIST OF TABLES }}$}

1 High Burn-Up Plutonium Isotopic Compositions Recommended. For Use In Shielding Analysis. . . . . . . . . . iij

2 Neutron Yields From $\alpha, n$ Reactions and Spontaneous Fission. . 3

3 Gamma Spectra and Yields ............... 4

4 Half-Lives of Plutonium and Daughters Which Contribute Significantly to Radiation Exposure. . . . . . . . 5

5 Mean Isotopic Compositions From Plutonium Recycle. . . . . 8

6 Average Composition of Plutonium Available For Recycle . . 9

7 Plutonium Isotopic Compositions Discharged From The Uranium Cycle. . . . . . . . . . . . . . 10

8 Plutonium Isotopic Composition Discharged From The First Plutonium Recycle............... 11

9 Plutonium Isotopic Composition Discharged From The Second Plutonium Recycle.............. 12

10 Plutonium Isotopic Compositions From The Third Plutonium -Recycle. .............. 13

11 Ratio of Individual Plutonium Isotopes to Pu-239 in Discharged LWR Fuel ...............

\section{LIST OF FIGURES}

1 Actual and Simplified Transmutation Paths Used in the Zodiac Program............... 17

2 Plutonium Isotopic Decay Daughters .......... 18 
, 


\section{HIGH BURN-UP PLUTONIUM ISOTOPIC COMPOSITIONS RECOMMENDED FOR USE IN SHIELDING ANALYSIS \\ M. G. Zimmerman \\ Battelle-Pacific Northwest Laboratories}

\section{INTRODUCTION}

The purpose of this report is to provide a set of reference isotopic compositions for plutonium that can be used in shielding and dose rate calculations for new, near-future plutonium plants. It is anticipated that as more data become available, these compositions may be adjusted slightly.

\section{DISCUSSION}

In order to select a reasonable and conservative plutonium isotopic content for use in shielding calculations several factors must be considered. These are:

- Burnup and radiation history of the fuel

- Time after reprocessing

- Shield material and thicknesses expected to be used

- Chemical form of the plutonium

The burnup and irradiation history of the nuclear fuel determines the actual plutonium isotopic composition at discharge. The relative contribution to radiation exposure of each plutonium isotope will be determined by the shielding material and thickness. Radiation exposure and shielding needs will be increased by the buildin as a function of time of certain daughter isotopes of plutonium such as Am-241 and U-237. The chemical form of the plutonium will determine the number of $(\alpha, \eta)$ reactions and hence the total neutron source.

The important assumption is the ratio of $\mathrm{Pu}-236, \mathrm{Pu}-238, \mathrm{Pu}-239, \mathrm{Pu}-240$, $\mathrm{Pu}-241$, and Pu-242 isotopes in the plutonium. Each of these isotopes have different radiation characteristics. The percentage of each in any given plutonium is determined by the characteristics and duration in the reactor where the plutonium was produced. Once the spent fuel (and plutonium) is 
,

. 
discharged from the reactor, however, the plutonium isotopic ratios are essentially fixed. Knowing these approximate ratios is important in shielding and dose rate analysis. Details of these considerations are given below.

\section{PLUTONIUM ISOTOPE PRODUCTION}

The plutonium isotopes are produced by neutron absorption and subsequent radionuclide decay of $U-235$ and $U-238$. The major process is that for U-238 shown below:

$$
\begin{aligned}
& 238 U+n \rightarrow 239 u+r \\
& 239 \mathrm{U} \rightarrow{ }^{239} \mathrm{~Np}+\mathrm{e}^{-} \\
& { }^{239} \mathrm{~Np} \rightarrow \cdot{ }^{239} \mathrm{Pu}+\mathrm{e}^{-} \quad \mathrm{t}_{1 / 2}=2.35 \text { days }
\end{aligned}
$$

This process occurs when U-238 absorbs a neutron with less energy then necessary to fission the U-238 isotope. A similar process occurs less frequentiy with $U-235$

$$
\begin{aligned}
& 235 \mathrm{U}+\mathrm{n} \rightarrow 236 \mathrm{2}+\gamma \\
& 236 U+n \rightarrow 237 U+\gamma \\
& { }^{237} \mathrm{U} \rightarrow{ }^{237} \mathrm{~Np}+\mathrm{e}^{-} \quad \mathrm{t}_{\mathrm{T} / 2}=6.75 \text { days } \\
& 237 \mathrm{~Np}+\mathrm{n} \rightarrow{ }^{238} \mathrm{~Np}+\gamma \\
& { }^{238} \mathrm{~Np} \rightarrow{ }^{238} \mathrm{Pu}+\mathrm{e}^{-} \quad t_{1 / 2}=2.12 \text { days }
\end{aligned}
$$

Other isotopes of plutonium usually present are $\mathrm{Pu}-240, \mathrm{Pu}-241$ and $\mathrm{Pu}-242$. These are formed by neutron absorption in Pu-239. The possible neutron absorptions and decays causing buildup of plutonium isotopes and other transuranic isotopes is shown in Figure 1. (1) The isotope Pu-236 is also produced to a small extent.

The various amounts of plutonium isotopes produced by these reactions are dependent on the cross-sections involved; and the effective cross-sections are determined by the neutron spectra. Therefore, the plutonium isotopic composition at discharge is determined by the burnup history and fuel parameters and the beginning plutonium isotopic composition of the fuel. 


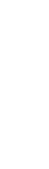


As the plutonium is recycled the relative isotopic production trends wil1 continue. The trend consists of a reduction in Pu-239 fraction, 1 ittle change in the fraction of $\mathrm{Pu}-240$ and $\mathrm{Pu}-241$ and an increase in the fraction of the other isotopes.

Only Pu-239 and Pu-24l are fissile. The relative fraction of fissile plutonium $(\mathrm{Pu}-239+\mathrm{Pu}-241)$ decreases with each recycle. Because of this, a greater amount of plutonium must be added to a given core for each recycle to achieve the same burnup. This means that eventually it becomes uneconomical to recycle the plutonium. At this point the plutonium is either discarded or used in LMFBR's. Our estimate is that plutonium wizz not be recycled beyond four times.

\section{RADIATION AND SHIELDING CHARACTERISTICS OF PLUTONIUM ISOTOPES}

In order to estimate reasonably conservative isotopic compositions it is necessary to consider the shielding problems associated with the different isotopes. The neutron and gamma yields for the different plutonium isotopes are shown in Tables 2 and $3 .(2)$

TABLE 2. Neutron Yields From $\alpha, n$ Reactions and Spontaneous Fission

$\mathrm{n} / \mathrm{sec}$ gram of $\mathrm{Pu}$

\begin{tabular}{l|l|l|l|l|l|l} 
Isotope & $\mathrm{PuO}_{2}$ & $\mathrm{PuF}_{4}$ & $\mathrm{PuC}$ & $\mathrm{PuBE}^{(\mathrm{n})}$ & $\left.\mathrm{Pu}_{\mathrm{NO}}\right)^{(\mathrm{b})}$ & $\begin{array}{c}\text { Spontaneous } \\
\text { Fission }\end{array}$ \\
\hline $\mathrm{Pu}-236$ & - & - & - & - & - & $3.7 \times 10^{4}$ \\
$\mathrm{Pu}-238$ & $1.34 \times 10^{4}$ & $2.04 \times 10^{6}$ & $1.49 \times 10^{4}$ & $4.38 \times 10^{7}$ & $2.7 \times 10^{4}$ & $2.62 \times 10^{3}$ \\
$\mathrm{Pu}-239$ & 38 & $6.35 \times 10^{3}$ & 37.3 & $1.36 \times 10^{5}$ & 76 & .03 \\
$\mathrm{Pu}-240$ & $1.45 \times 10^{2}$ & $2.35 \times 10^{4}$ & 137.8 & $5.02 \times 10^{5}$ & $2.9 \times 10^{2}$ & $1.02 \times 10^{3}$ \\
$\mathrm{Pu}-241$ & - & - & - & - & - & - \\
$\mathrm{Pu}-242$ & 2.13 & $2.83 \times 10^{2}$ & - & - & 4.2 & $1.7 \times 10^{3}$ \\
$\mathrm{Am}-241$ & $2.68 \times 10^{3}$ & $4.08 \times 10^{5}$ & $2.98 \times 10^{3}$ & $8.76 \times 10^{6}$ & $5.46 \times 10^{3}$ & - \\
\hline
\end{tabular}

(a) Estimated from Reference 13.

(b) A rough estimate indicates an approximate doubling of $(\alpha, n)$ yields compared to $\mathrm{PuO}_{2}$. 
. 
TABLE 3. Gamma Spectra and Yields

gammas/100 disintegrations

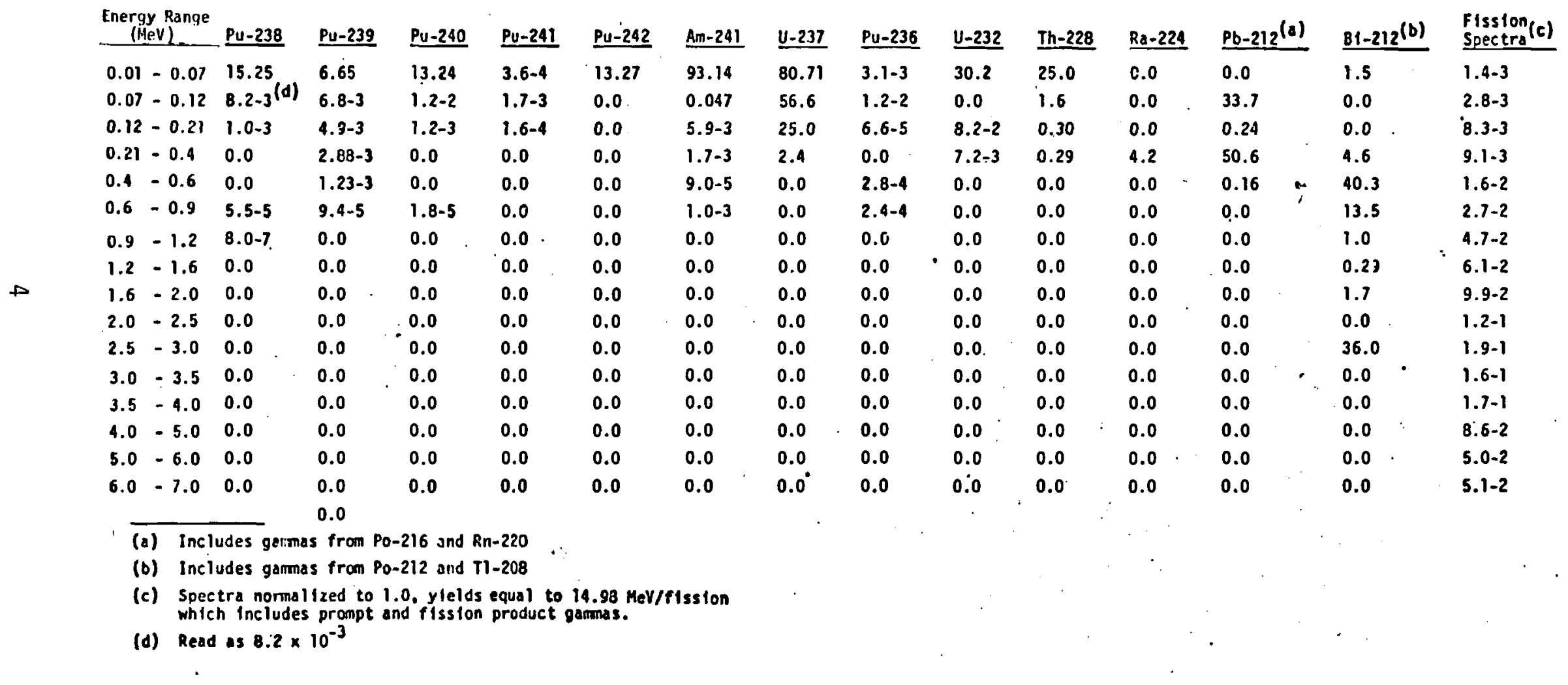




.


The major contributors to the dose rate in a given plutonium isotopic composition will depend on the shielding, geometry, and age since reprocessing. The half-lives of the plutonium isotopes and the daughters which contribute to the shielding problem are shown in Table 4.

TABLE 4. Half-Lives of Plutonium and Daughters which Contribute Significantly To Radiation Exposure(11)

\begin{tabular}{|c|c|c|c|}
\hline$\underline{\text { Daughters }}$ & Parents & $\begin{array}{l}\text { Radioactive } \\
\text { Decay Half-Life }\end{array}$ & $\begin{array}{l}\text { Spontaneous } \\
\text { Fission Half-Life }\end{array}$ \\
\hline Pu-236 & - & $2.85 \mathrm{yr}$ & $3.5 \times 10^{9} \mathrm{yr}$ \\
\hline $\mathrm{Pu}-238$ & - & $86.4 \mathrm{yr}$ & $4.9 \times 10^{10} \mathrm{yr}$ \\
\hline $\mathrm{Pu}-239$ & - & $24390 \mathrm{yr}$ & $5.5 \times 10^{15} \mathrm{yr}$ \\
\hline $\mathrm{Pu}-240$ & - & $6580 \mathrm{yr}$ & $1.34 \times 10^{11} \mathrm{yr}$ \\
\hline $\mathrm{Pu}-241$ & - & $13.2 \mathrm{yr}$ & - \\
\hline $\mathrm{Pu}-242$ & - & $3.79 \times 10^{5} \mathrm{yr}$ & $7.1 \times 10^{10} \mathrm{yr}$ \\
\hline$A m-241$ & $P u-241$ & 458 yr & $2.0 \times 10^{14} \mathrm{yr}$ \\
\hline$U-237$ & $P u-241$ & 6.75 day & - \\
\hline$U-232$ & $P u-236$ & $72 \mathrm{yr}$ & $8 \times 10^{13} \mathrm{yr}$ \\
\hline Th-228 & $U-232$ & $1.91 \mathrm{yr}$ & - \\
\hline $\mathrm{Ra}-224$ & $. T h-228$ & 3.64 day & - \\
\hline $\mathrm{Rn}-220$ & $\mathrm{Ra}-224$ & $55.3 \mathrm{sec}$ & - \\
\hline Po-216 & $R n-220$ & $0.145 \mathrm{sec}$ & - \\
\hline $\mathrm{Pb}-212$ & Po-216 & $10.64 \mathrm{hr}$ & - \\
\hline$B i-212$ & $\mathrm{~Pb}-212$ & $60.6 \mathrm{~min}$ & - \\
\hline Po-212 & $B i-212$ & $0.304 \mu \mathrm{sec}$ & \\
\hline T1-208 & $B i-212$ & $3.10 \mathrm{~min}$ & - \\
\hline
\end{tabular}

Since each isotope has a different activity, the radiation source strength is determined by the isotopic composition. However, each isotope has a different gamma and $x$-ray spectra, and the isotope responsible for most of the dose rate can change depending on the shield thickness and geometry. In conditions of no shielding or very thin shields like hood gloves, the major contributors to the dose rate are those isotopes producing the most low energy gammas and $x$-rays. For this reason a geometry of plutonium with little self-shielding may produce a much greater dose rate then an equivalent amount of plutonium in a small dense source. 


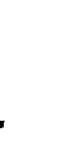


Several isotopes, notably Pu-236 and Pu-241 decay to daughters which contribute a significant dose rate. For this reason the time after reprocessing can change the relative contribution of the plutonium isotopes to the dose rate.

Most of the preceding discussion applies only to the gamma source. Because the neutron spectra from the different isotopes are essentially the same for shielding purposes, the geometry and shield thickness has little effect on the relative contribution to the dose rate by the different isotopes. Therefore, the dominate plutonium isotope from a neutron shielding standpoint is determined solely by the isotopes activity and density compared to the other plutonium isotopes.

The neutron and gamma radiation characteristics for each isotope are discussed below:

$\underline{\text { Pu-236 }}$

Typically recycle plutonium is expected to contain less then 0.1 ppm Pu-236. This isotope does not contribute significantly to neutron dose rates and the gamma dose rate is smal1 compared to that from other isotopes. However because of decay daughters, the gamma dose rate will buildup with time. The decay scheme is shown in Figure 2. Equilibrium conditions will be reached in about 18 years. The major shielding problem is a $2.6 \mathrm{MeV}$ gamma from T1-208. Because of the high energy of this gamma ray, this isotope can contribute significantly to the dose rate under conditions of thick shields and several years time since reprocessing.

$\underline{\mathrm{Pu}-238}$

The amount of Pu-238 varies from about $1 \%$ to about $5 \%$ of the plutonium. This isotope, because of its abundance and relatively short half-life, is a major contributor to the dose rate. The gammas are mostly low energy and can be shielded by thin shields. However, there are enough high energy gammas to dominate the gamma dose rate if the shields are of the proper thickness. 
. 
The Pu-238 can also be the major contributor to the neutron dose rate. This is especially true in compounds with a potential for $(\alpha, n)$ reactions. The spontaneous fission half-life is also relatively short. Pu-239

Pu-239 generally contributes less to the dose rate on a per atom basis then any of the others. The half-life for Pu-239 is much longer then for the other isotopes except $\alpha$-decay of Pu-242. Only when Pu-239 makes up essentially all of the plutonium is it a major contributor to the dose rate. The Pu-239 can make up a significant portion of the gamma dose rates through thin lead shields. The Pu-239 can be more important if the dose rate due to induced fissions caused by neutron multiplication is significant. Since the Pu-239 and the Pu-241 are the only fissile isotopes, the neutron multiplication will depend on the amount of these isotopes.

$\mathrm{Pu}-240$

Pu-240 may be about $25 \%$ of the plutonium. The gamma dose rate is mostly from low energy gammas and even thin shields reduce the contribution to insignificance.

This isotope can contribute about half of the neutron dose rate. This is due to both spontaneous fission and $(\alpha, n)$ neutrons.

$\underline{\mathrm{Pu}-241}$

Pu-24.1 may be about 17\% of the plutonium. This isotope contributes primarily to the gamma dose rate through its daughters U-237 and Am-241. The decay scheme is shown in Figure 2. These isotopes are major contributors to the gamma dose rate for most shielding situations. The U-237 builds in to equilibrium within a month and the Am-241 builds in to significant levels in about a year after reprocessing.

$\mathrm{Pu}-241$ contributes very little to the neutron dose rate. The Am241 can contribute a small amount to the neutron dose rate through $(\alpha, n)$ reactions. Pu-241 is also fissile and may contribute to the induced fission neutron dose rate.

$\underline{\mathrm{Pu}-242}$

Pu-242 may be about 15\% of the plutonium. This isotope contributes insignificantly to the ganma dose rate. 
.

. 
Pu-242 does contribute significantly to the neutron dose rate. This is mostly from spontaneous fission al though some $(\alpha, n)$ neutrons can also be present.

From the foregoing discussion of the individual plutonium isotopes we can conclude that a11 the isotopes can contribute significantly to dose rates for differing conditions. However, in most instances in fabrication and reprocessing steps for plutonium recycle, the major contributors are Pu-238 and Pu-241 for the gamma dose rate and Pu-238, Pu-240 and Pu-242 for the neutron dose rate. Under conditions of thick shielding and long storage time, Pu-236 daughters may contribute a significant amount to the gamma dose rate. The proportions of the dose rate from these isotopes will vary depending on what shielding is employed and the specific isotopic composition.

Therefore in order to choose conservative isotopic compositions for recycle plutonium we would generally choose the composition with the least Pu-239 and the most Pu-238 and Pu-241. Generally the compositions with the most Pu-238 and Pu-241 would also have the most Pu-240 and Pu-242. However, in those cases where induced fissions are important we may want to choose a composition with the most Pu-239 and Pu-241 in order to assure conservatism.

REPORTED PLUTONIUM ISOTOPIC COMPOSITIONS FOR U0 ${ }_{2}$ AND PU-UO ${ }_{2}$ FUELS

We have investigated several references for the isotopic composition of recycle plutonium. The mean isotopic composition and the range of vaiues found for each isotope is shown in Table 5.

TABLE 5. Mean Isotopic Compositions From Plutonium Recycle

\begin{tabular}{|c|c|c|c|c|}
\hline & $\begin{array}{l}\text { Equil ibrium } \\
\text { Uranium } \\
\text { Cycle } \\
\end{array}$ & $\begin{array}{l}\text { First Pu } \\
\text { Recycle } \\
\end{array}$ & $\begin{array}{l}\text { Second Pu } \\
\text { Recycle } \\
\end{array}$ & $\begin{array}{l}\text { Third Pu } \\
\text { Recycle }\end{array}$ \\
\hline Pu-236 & $0.08 \mathrm{ppm}$ & $0.06 \mathrm{ppm}$ & $0.06 \mathrm{ppm}$ & - \\
\hline Pu-238 & $1.9 \pm .6$ & $2.3 \pm 1.0$ & $3.4 \pm 1.5$ & $4.3 \pm 0.7$ \\
\hline Pu-239 & $57.8 \pm 3.4$ & $46.9 \pm 9.2$ & $38.2 \pm 8.8$ & $29.0 \pm 2.0$ \\
\hline Pu -240 & $23.7 \pm 2.3$ & $28.0 \pm 4.0$ & $30.3 \pm 3.3$ & $29.8 \pm 2.8$ \\
\hline$P u-241$ & $12.2 \pm 2.1$ & $16.0 \pm 4.0$ & $16.2 \pm 8.2$ & $18.8 \pm 2.8$ \\
\hline Pu -242 & $4.2 \pm 1.1$ & $10.0 \pm 5.0$ & $11.7 \pm 3.7$ & $19.2 \pm 0.8$ \\
\hline
\end{tabular}


From this table we averaged the values for our recommendation in Table 1. In order to get the fourth plutonium recycle results in Table 1 we extrapolated the results for the first three recycles. Also, we show in Table 6 the predicted average plutonium isotopic composition for 1975, $1980,1985 .{ }^{(3)}$ The various isotopic compositions from the individual references are shown in Tables $7,8,9$, and 10. From these tables we can observe that there is a large variation in plutonium isotopic composition between the different sources.

TABLE 6. Average Composition of Plutonium Available for Recycle $e^{(3)}$

\begin{tabular}{|c|c|c|c|c|c|c|}
\hline Year & ${ }^{236} \mathrm{Pu}$ & ${ }^{238} \mathrm{Pu}$ & ${ }^{239} \mathrm{Pu}$ & ${ }^{240} \mathrm{Pu}$ & ${ }^{241} \mathrm{Pu}$ & ${ }^{242} \mathrm{Pu}$ \\
\hline 1975 & 0.000006 & 1.0 & 64 & 22 & 10 & 3 \\
\hline 1980 & 0.0000007 & 1.5 & 58 & 24 & 11 & 5 \\
\hline 1985 & 0.0000007 & 1.7 & 54 & 25 & 12 & 7 \\
\hline
\end{tabular}

This variation in results from the different references is explained mostly by the burnup assumed. During exposure of the fuel in a reactor core, the production of plutonium is not constant with time. Initially when most of the power is produced from U-235 fissions, only a small amount of plutonium is produced. As the U-235 is burned out and more power is produced from $\mathrm{Pu}-239$ the effective production rate for the Pu-238, Pu-240, Pu-241 and Pu-242 isotopes increases relative to Pu-239. Therefore, the production rate of these isotopes is greatest just before the fuel is discharged. In the cases where fuel burnup and enrichment was given by the references used for this report, the burnup was about 27,000 MWD/MT for BWRs and 33,000 MWD/MTM for PWRs with $2.7 \%$ enrichment for BWRs to $3.3 \%$ enrichment for PWRs.

The isotopic compositions are generally based on average core burnups. Some portions of the fuel may achieve higher burnups and therefore higher proportions of Pu-238, Pu-241 and Pu-242. Likewise other portions of the core will achieve lower burnup. Therefore the plutonium isotopics given can only be considered as approximate averages of the actual plutonium isotopic composition. 

TABLE 7. Plutonium Isotopic Compositions Discharged From The Uranium Cycle

\begin{tabular}{|c|c|c|c|c|c|c|c|c|c|c|c|c|c|}
\hline & $\begin{array}{l}\text { Plutonium } \\
\text { from Firs } \\
\text { Cycle, wt }\end{array}$ & $\begin{array}{l}\text { omposition } \\
\text { Uranium }\end{array}$ & & & $\mathrm{Plu}$ & un Com & tion & Equil & ium Ura & Cycle, & & & \\
\hline & $(9)^{(a)}$ & (3) & (3) & (5) & (6) & $(6)$ & (7) & (8) & (10) PWR & (10) BWR & (1) & (15)PWR & $(15) \mathrm{BWR}$ \\
\hline $\mathrm{Pu}-236$ & - & $0.004 \mathrm{ppm}$ & $\mid 0.07 \mathrm{ppm}$ & - & - & - & - & - & - & - & $8.8-06$ & - & - \\
\hline$P u-238$ & 1 & 0.6 & 1.6 & 2.5 & 2 & 2.5 & 1.9 & 1.9 & 1.5 & 1.3 & 1.5 & 1.5 & 1.35 \\
\hline Pu-239 & 70 & 69 & 56 & 57 & 61 & 55.5 & 57.9 & 59.2 & 58.0 & 61.3 & 54.5 & 55. & 55.1 \\
\hline$P u-240$ & 17 & 20 & 26 & 23 & 24 & 23.6 & 24.7 & 24.0 & 22.8 & 21.4 & 21.6 & 23.9 & 26.0 \\
\hline Pu-24l & 10 & 8 & 11 & 11 & 10 & 13.5 & 11.0 & 11.1 & 13.6 & 12.7 & 12.5 & 14.3 & 12.7 \\
\hline $\mathrm{Pu}-242$ & 2 & 2 & 5 & 5.2 & 3 & 4.9 & 4.4 & 3.8 & 4.3 & 3.4 & 4.9 & 5.3 & $4.8^{\circ}$ \\
\hline
\end{tabular}

a. These numbers refer to the references. 


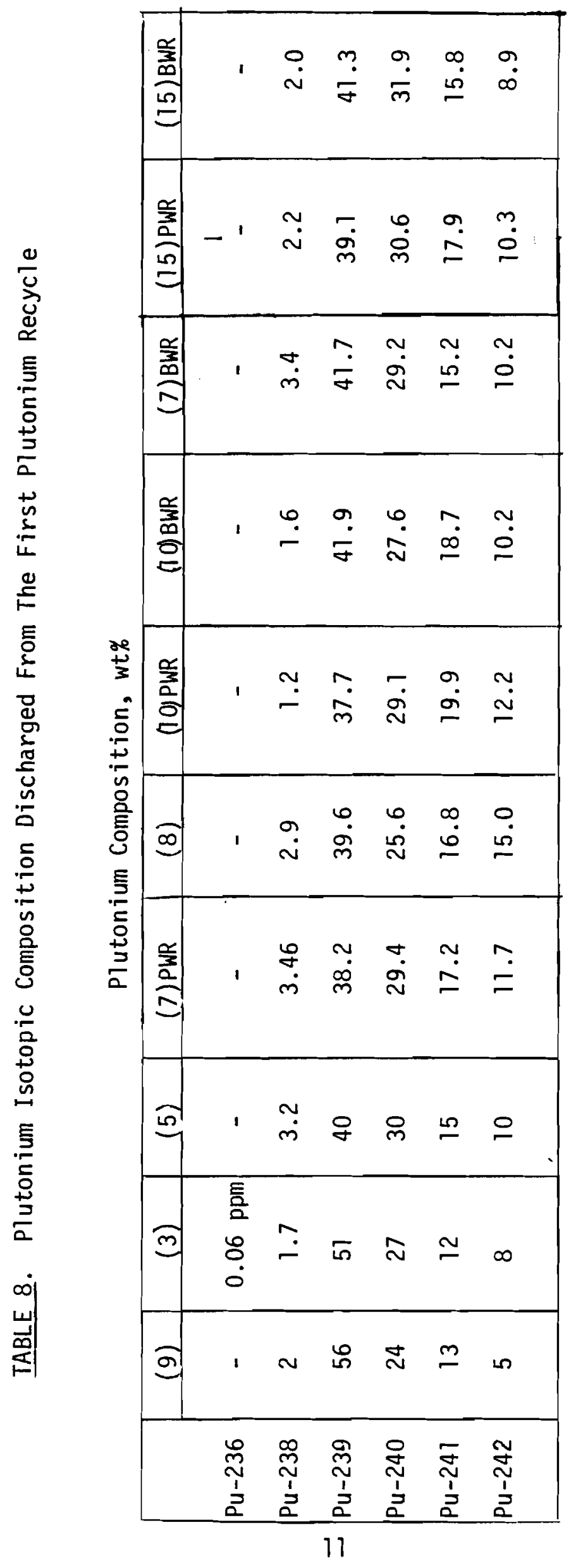


. 
TABLE 9. Plutonium Isotopic Composition Discharged From The Second Plutonium Recycle

\begin{tabular}{lcccccc} 
& \multicolumn{7}{c}{ Plutonium Composition, wt\% } \\
\cline { 2 - 6 } & $(9)$ & $(3)$ & $(5)$ & $(7)$ & $(15)$ PWR & (15)BWR \\
\hline Pu-236 & - & $0.06 \mathrm{ppm}$ & - & - & - & - \\
$\mathrm{Pu}-238$ & 4 & 1.9 & 4.2 & 4.9 & 2.9 & 2.8 \\
$\mathrm{Pu}-239$ & 47 & 47 & 34 & 29.4 & 32.2 & 33.7 \\
$\mathrm{Pu}-240$ & 28 & 27 & 30 & 33.5 & 30.1 & 32.4 \\
$\mathrm{Pu}-241$ & 13 & 13 & 16 & 17.4 & 19.4 & 17.7 \\
$\mathrm{Pu}-242$ & 8 & 11 & 15 & 14.9 & 15.4 & 13.5 \\
& & & & & & \\
\hline
\end{tabular}

Other reasons for the differences observed in Tables 7-10 include differences in cross-sectional data and sophistication of techniques. The older results especially may be incorrect because of new cross-sectional data made available since they were calculated.

A comparison of our average isotopic composition in Table 1 and two other references is shown in Table 11. These two references did not present the ${ }^{238} \mathrm{Pu} w \mathrm{w} \%$, therefore the comparison is made as a function of the ratio of the amount of a given plutonium isotope to that of ${ }^{239} \mathrm{Pu}$. The results from references 15 and 16 differ from the Table 1 averages, however, the range of values in Tables 6 and 7 includes the values for the 1 st and 2 nd plutonium recycles from references 15 and 16 in Table 11 . The third and fourth recycle values from Table 1 differ from those values given in references 15 and 16 because of the way in which the plutonium is recycled. The recycle plutonium given in Table 1 has been segregated. Segregation means that the plutonium from the first plutonium recycle is recycled separately from other plutonium into the second recycle and similarly into the third and fourth recycle. In references 15 and 16, the plutonium from each recycle step is mixed with plutonium from the rest of the $\mathrm{UO}_{2}$ fueled core. This reduces the amounts of ${ }^{240} \mathrm{Pu},{ }^{241} \mathrm{Pu}$, and ${ }^{242} \mathrm{Pu}$ relative to ${ }^{239} \mathrm{Pu}$. The conservative approach for shielding analysis is to assume the plutonium is segregated. 


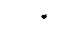


TABLE 10. Plutonium Isotopic Compositions From The Third Plutonium Recycle

\begin{tabular}{lccc} 
& \multicolumn{3}{c}{ Plutonium Composition, wt\% } \\
\cline { 2 - 4 } & $\underline{(5)}$ & $\underline{(15) \mathrm{PWR}}$ & $\underline{(16) \mathrm{BWR}}$ \\
Pu-236 & - & - & - \\
Pu-238 & 5 & 3.7 & 3.6 \\
Pu-239 & 31 & 27.0 & 27.8 \\
Pu-240 & 27 & 28.3 & 32.5 \\
Pu-241 & 16 & 21.5 & 18.7 \\
Pu-242 & 20 & 19.4 & 18.4
\end{tabular}




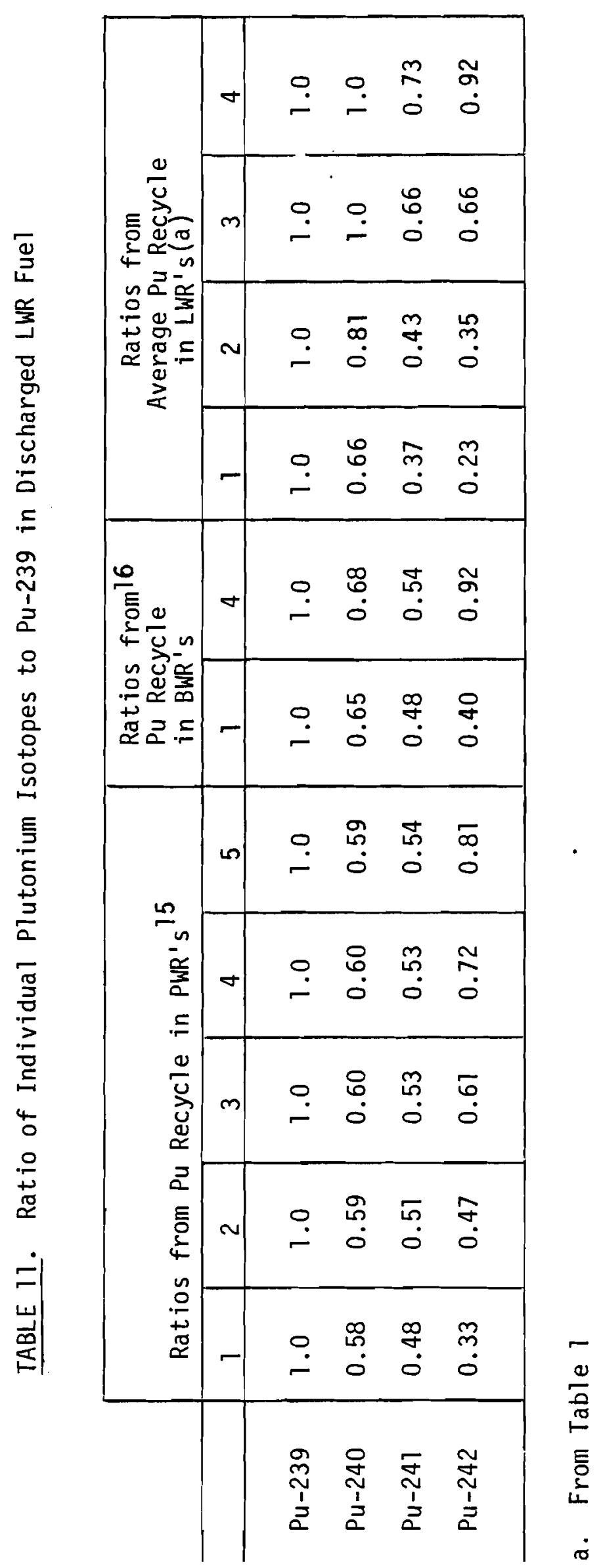


It would be difficult to include references 15 and 16 results in the averages because no ${ }^{238} \mathrm{Pu}$ values are given. The ${ }^{238} \mathrm{Pu}$ cannot be ignored in the shielding analysis. 
.

. 


\section{REFERENCES}

1. D. L. Prezbindowski, Calculation of ${ }^{236} \mathrm{Pu}$ and ${ }^{238} \mathrm{Pu}$ in the Discharge Fuel of Light Water Power Reactors, BNWL-1523, September 1970.

2. M. G. Zimmerman and D. H. Thomsen, A Shielding Calculational System for Plutonium. BNWL-1855, August $19 \overline{75 .}$

3. D. E. Deonigi, "The Value of Plutonium Recycle in Thermal Reactors," Nuclear Technology, Volume 18, May 1973.

4. H. H. Van Tuyl, Calculation of Gamma Dose Rates at the Surfaces of Plutonium Oxide Sources, BNWL-1259, January 1970.

5. A. J. Snyder, Computer Program NUFUEL for Forecasting Nuclear Fuel Requirements and Related Quantities," WASH-1348, UC-80, October, 1974.

6. USNRC, Final Generic Environmental Statement on the Use of Recvcle Plutonium in Mixed Oxide Fuel in Light Water Cooled Reactors (GESMO), NUREG-0002, Vo1. 3, August 1976.

7. J. J. Wachter, Model Plutonium Recycle Reactor for Environmental Analysis of the Mixed Oxide Fuel Cycle, ORNL-5118, 1976.

8. M. J. Bell, Heavy Element Composition of Spent Power Reactor Fuels, ORNL-TM-2897, May 1970.

9. G. H. Bryan, et.a1., Results of Research to Evaluate Solid Plutonium Nitrate as a Safe Shipping Form, BNWL-1941, November 1976.

10. "Theoretical Analysis of Plutonium Buildup and Uranium Depletion in Pressurized Water and Boiling Water Power Reactors," Battelle-Northwest for IAEA, Y49024, July 1968.

11. C. M. Lederer, J. M. Hollander, and I. Perlman, Table of Isotopes, 6th ed., John Wiley \& Sons, 1967.

12. L. Van Der Zwan, "Calculated Neutron Spectra from $\mathrm{Be}^{9}(\alpha, n)$ Sources," Canadian Journal of Physics, 46, 1527, 1968.

13. R. H. Holeman and D. D. Matsumoto, ZODIAC (2+2) A Revision to ZODIAC 2, BNWL-459, Pacific Northwest Laboratory, Richland, Washington, May 1967.

14. D. F. Newman, R. M. Fleischman, and M. R. White, "Implications of Plutonium Utilization Strategies on the Transition from an LWR Economy to a Breeder Economy," Topical Meeting on the Plutonium Fuel Cycle, American Nuclear Society, Bal Harbour, Florida, May 2-4, 1977.

15. B. L. Vondra, LWR Fuel Reprocessing and Recycle Program Quarterly Report for Period Apri] 1 to June 30, 1976, ORNL/TM-5547, July 1 , 1976.

16. B. L. Vondra, LWR Fuel Reprocessing and Recycle Program Quarterly Report for Period July 1 to September 30, 1976, ORNL/TM-5660, November 1976. 


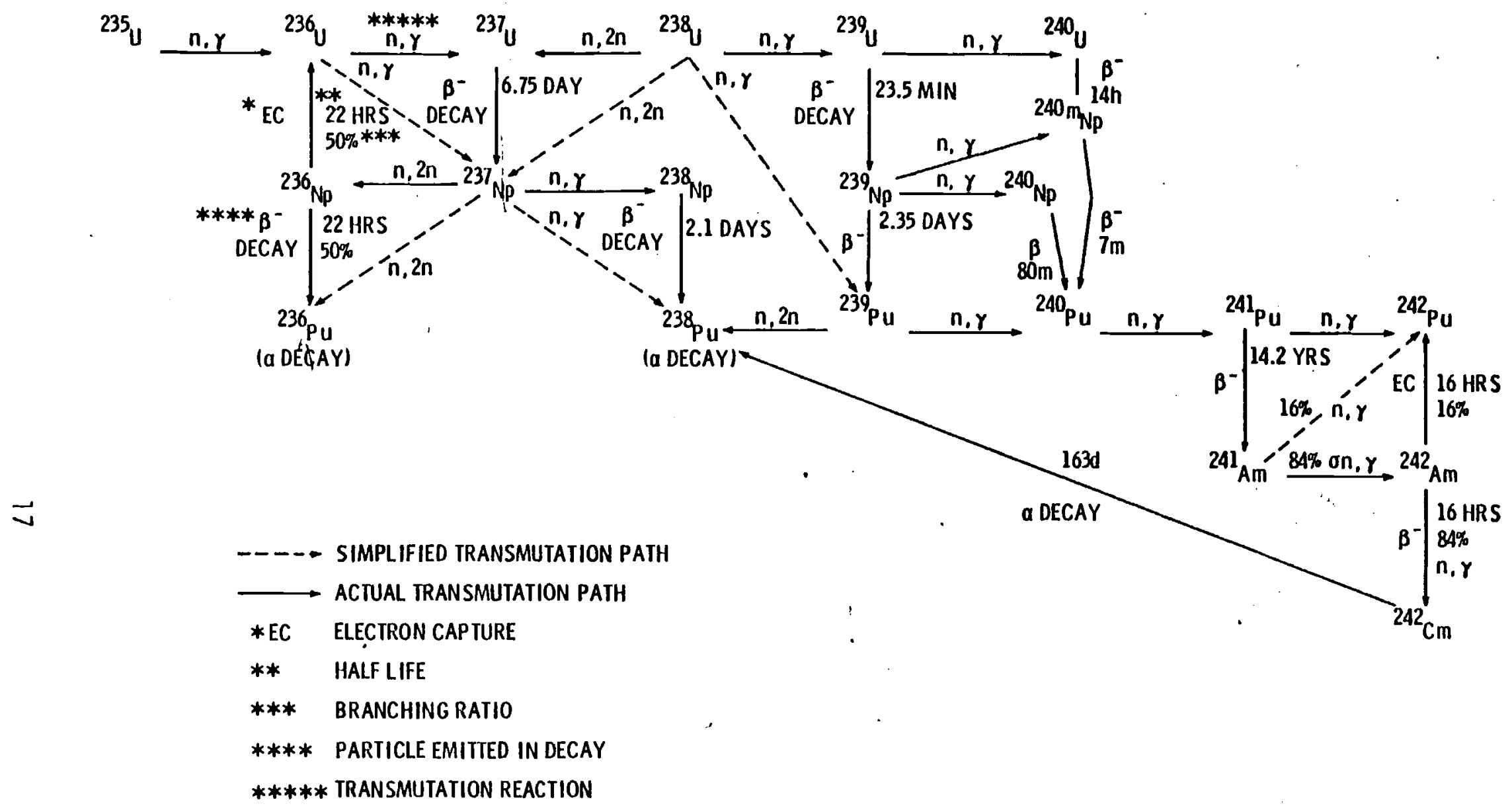

FIGURE 1. Actual and Simplified Transmutation Paths Used in the Zodiac Program (14) 


\section{Figure 2}

Plutonium Isotopic Decay Daughters (a)

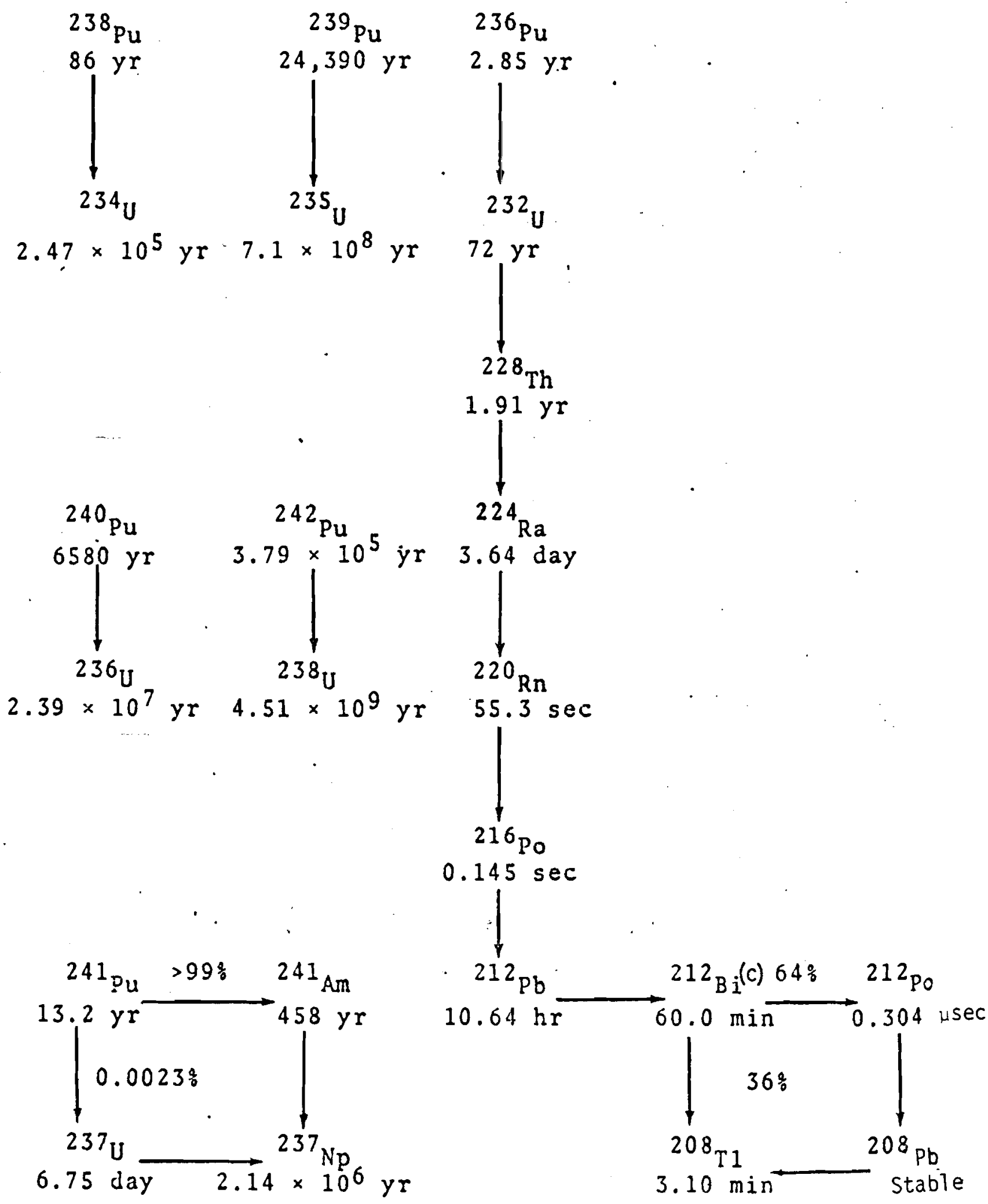

(a) From B!!!L-1259 - reference 4. 

r 


\section{DISTRIBUTION}

No. of

Copies

OFFSITE

1 ERDA Chicago Patent Group

9800 South Cass Avenue

Argonne, IL 60439

A. A. Churm

1 ERDA Albuquerque Operations office P. 0. Box 5400

A1 buquerque, NM 87115

ERDA Chicago Operations Office

9800 South Cass Avenue

Argonne, IL 60439

1 ERDA Division of Biomedical and Environmental Research washington, DC 20545

J. L. Liverman, Director

1 ERDA Division of International Affairs Washington, DC 20545

N. F. Seivering, Asst. Admin.

$1 \quad$ ERDA Nuclear Energy

Washington, DC 20545

R. W. Roberts, Asst. Admin.

1 ERDA Division of Reactor

Development Demonstration

washington, DC 20545

Chief, Fuel Recycle Branch

1 ERDA Division of Safeguards and Security Washington, DC 20545

H. E. Lyon
No. of

Copies

OFFSITE

8 ERDA Division of Waste Management Production and Reprocessing Washington, DC 20545

G. W. Cunningham, Director

G. Bradley

K. Burson

P. Hogroian

C. Kuhlman

W. McVey

G. Pleat

D. Spurgeon

1 ERDA Idaho Operations office 550 2nd Street Idaho Falls, ID 83401

1 ERDA Oak Ridge Operations Office P. 0. Box E

Oak Ridge, TN 37830

2 ERDA San Francisco Operations Office

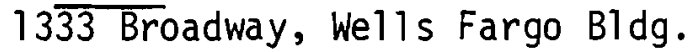
Oakland, CA 94616

1 University of Cal ifornia Lawrence Livermore Laboratory Livermore, CA 94550

3 ERDA Savannah River Operations Office P. O. Box "A"

Aiken, SC 29801

T. B. Hindman, Jr., Director, Fuel Cycle Project Office Norman Hook

N. Stetson, Manager

27 ERDA Technical Information Center 
No. of

Copies

OFFSITE

1 Aerojet, Energy Conversion

Company

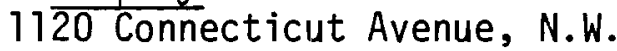

Suite 1050

Washington, DC 20036

F. J. Kierman, Eastern

Regional Manager,

Energy Systems

1 Allied Chemical Corporation

550 Second Street

Idaho Falls, ID 83401

F. H. Anderson, General Manager

2 Allied-General Nuclear Services

P. 0. Box 847

Barnwe11, SC 29812

A. E. Schubert, President

A. K. Williams

1 Argonne National Laboratory

9700 South Cass Avenue

Argonne, IL 60439

J. A. Kyger, Assoc. Director

1 Atlantic Richfield Company

Box 2679 - TA

Los Angeles, CA 90071

L. M. Richards, Coordinator, Nuclear Comm. Dev.

1 Babcock and Wilcox

P. 0. Box 1260

Lynchburg, VA 24505

R. H. Ihde, Manager, Contracts and Marketing

1 Battel le-Columbus Laboratories

505 King Avenue

Columbus, $\mathrm{OH} 43201$

J. M. Batch, Director
No. of

Copies

OFFSITE

3 Battelle-Human Affairs Research Centers $40 \overline{00 ~ N . E . ~} 41$ st Street Seattle, WA 98105

S. M. Nealey

J. E. Rasmussen, Director

C. R. Schuller

$1 \quad$ Boeing Engineering and

Construction Division

P. 0 . Box 3707

Seattle, WA 98124

Richard L. Grant, Director, Nuclear Projects

1 Burns and Roe, Industrial Services Corporation

P. 0. Box 663

Paramus, NJ 07652

M. I. Naparstek, Manager, Proposals

$1 \quad$ Combustion Engineering Nuclear Power Division 1000 Prospect Hill Road Windsor, CT 06095

C. K. Anderson

1 Commonwealth Edison Company

P. 0. Box 767

Chicago, IL 60690

G. R. Corey, Vice Chairman

1 Carol ina Power and Light Company P. 0. Box 1551

Raleigh, NC 27602

L. E. Smith, Manager, Fuel

1 Corning Glass Works Corning, NY 14830

M. G. Britton, Manager, Techinical Liaison 


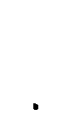


No. of

Copies

OFFSITE

1 DBM Corporation

1920 A1pine Avenue

Vienna, VA 22180

R. G. Cross

1 Edison Electric

90 Park Avenue

New York, NY 10016

J. Carp, Director, Energy Policy

E. I. duPont de Nemours and Company

Aiken, SC 29801

10 C. H. Ice, Director, SRL

10 J. Church, SRL

2 Exxon Nuclear Company, Inc. 777 - 106th Avenue, N.E. Bellevue, WA 98009

S. J. Beard

R. L. Dickeman, President

1 Florida Power Corporation

P. 0. Box 14042

St. Petersburg, FL 33733

A. H. Hines, Jr., President

1 Florida Power and Light Company

P. 0. Box 013100

Miami, FL 33101

Dr. Uhrig

$1 \quad$ General Atomic Company

P. 0. Box 81608

San Diego, CA 92138

John Shefcik

2 General Electric Company

175 Curtner Avenue

San Jose, CA 95125

R. G. Barnes

K. Bowlman
No. of

Copies

OFFSITE

1 GPU Services Corporation

260 Cherry Hill Road

Parsippany, NJ 07054

B. H. Cherry, Manager, Fuel Resources

1 Holmes and Narver, Inc. 400 E. Orangethorpe Avenue Anahe im, CA 92801

W. A. Kalk, Manager, Nu Power Systems

1 Los Alamos Scientific Laboratory P. 0. Box 1663 Los Alamos, NM 87545

H. M. Agnew, Director

$1 \quad$ Middle South Utilities, Inc. P. 0. Box 61005 New Orleans, LA 70161

F. W. Lewis, President

Kerr-McGee Nuclear Corporation

Kerr-McGee Building

Oklahoma City, OK 73102

Martin Binstock

Livermore Radiation Laboratories P. 0. Box 808

Livermore, CA 94550

Kenneth Street, Assoc. Director

1 Monsanto Research Corporation Mound Laboratory

P. 0 . Box 32

Miamisburg, $\mathrm{OH} 45332$

W. T. Cave, Director

$1 \quad \mathrm{NL}$ Industries

P. 0. Box 928

Barnwel1, SC 29812

George Stukenbroeker 
, 
No. of

Copies

OFFSITE

$1 \quad$ Niagara Mohawk Power Corp.

300 Erie Boulevard, West

Syracuse, NY 13202

G. K. Rhode, VP, Engineering

$1 \quad$ NRC Nuclear Materials Safety and Safeguards Washington, DC 20545

R. Cunningham

$1 \quad$ NRC Research

Washington, DC 20545

Saul Levine, Deputy Director

$1 \quad$ Nuclear Fuel Services, Inc. 6000 Executive Blvd. Rockville, MD 20952

R. W. Deuster, President

$1 \quad$ Oak Ridge Gaseous Diffusion Plant Oak Ridge, TN 27820

W. J. Wilcox, Technical Director

$1 \quad$ Oak Ridge National Laboratory

P. 0. Box X

Oak Ridge, TN 37830

Herman Postma, Director

1 Proposal Management, Inc.

121 N. Orionna Street

Philadelphia, PA 19106

C. A. Hirenda, Director, Marketing

1 Rockwel1 International

Atomics International Division

8900 De Soto Avenue

Canoga Park, CA 91304

R. D. 01denkamp

1 Rockwel 1 International

Rocky Flats Plant

P. 0. Box 464

Golden, CO 80401

R. 0. Williams, VP
No. of

Copies

OFFSITE

1 Science Applications, Inc.

1680 Hanover Street

Palo Alto, CA 94303

$1 \quad$ NUSAC

777 Leesburg Pike

Falls Church, VA 22043

R. C. Adkins, Technical

Representative

1 Tennessee Valley Authority

217 Electric Power Board B7 $d g$.

Chattanooga, TN 37401

Ray Hoskins

1 Thraeger Tech.

110 S. Euclid Avenue

Pasadena, CA 91101

K. Vickers

1 The S. M. Stoller Corp.

Western Reprocessors

1250 Broadway

New York, NY 10001

S. M. Stoller

1 Virginia Electric Power Co. Nuclear Fuel Service Dept.

512 Frankl in Building

P. 0. Box 26666

Richmond, VA 32361

$\mathrm{Cl}$ aude Stephens

1 Westinghouse Electric Corp.

PTutonium Recycle Fuel Programs

P. 0. Box 355

Pittsburgh, PA 15230

J. F. Bader, Manager

1 Yankee Atomic Electric Company

20 Turnpike Road

Westboro, MA 01581

Wendell Johnson, VP 

No. of

Copies

ONSITE

2

ERDA Richland Operations Office

P. A. Craig

N. T. Karagianes

$2 \quad$ ARHCO

H. H. Hopkins

M. J. Szul inski

3 Hanford Engineering Development Laboratory

M. J. Barr

R. E. Dah1, Jr.

R. B. McCord

58 Battelle-Northwest

L. E. Addison

R. P. Allen

G. S. Allison

T. W. Ambrose

W. J. BaiTey

D. E. Blahnik

D. W. Brite

C. L. Brown

L. M. Browne

L. L. Burger

N. E. Carter

D. B. Cearlock

E. D. Clayton

W. J. Coleman

J. W. Finnigan

R. M. Fleischman

M. D. Freshley

J. C. Fox

S. Goldsmith

A. J. Haverfield

E. R. Irish

J. H. Jarrett (2)

W. S. Kelly

R. S. Kemper

D. H. Lester

R. C. Lloyd

R. P. Marshall

E. T. Merritl

I. C. Nel son

R. D. Nel son

J. F. Nesbitt

D. F. Newman
No. of

Copies

ONSITE

Battelle-Northwest (contd)

J. M. Nielson

R. E. Nightingale

D. R. Oden

D. E. Olesen

G. B. Parker

L. T. Pedersen

A. M. Platt

W. E. Reardon

F. R. Reich

R. D. Scheele

L. C. Schwend iman

J. L. Simmons

C. L. Simpson

J. L. Swanson

C. M. Unruh

H. H. Van Tuyl

L. L. Wende11

R. D. Widrig

M. G. Zimmerman

Technical Information (5)

Technical Publications 
. 